\title{
PRELIMINARY NOTES \\ OF AN INQUIRY INTO THE PHYSIQUE OF GLASGOW SCHOOL CHILDREN.
}

\author{
By A. K. CHALMERS, M.D., \\ Medical Officer of Health, Glasgou.
}

$\mathrm{I}^{\mathrm{N}}$

$\mathrm{N}$ the winter of $1902-3 \mathrm{I}$ had occasion to inquire into the death-rate from several causes in houses of various sizes in Glasgrow, and this investigation served to bring into prominence the excessive mortality prevailing in the smaller-sized houses, but especially in single apartments. This was completed about the time when the Royal Commission on Physical Training (Scotland) issued their report, and the findings of that Commission suggested to me that along with the high death-rate in these smaller houses there might be coincident variations in the physical development of the children living in them, which would help to explain the excessive incidence of disease among their inhabitants.

In consequence, I suggested to the Chairman of the School Board and to the Convener of the Committee on Health the desirability of an inquiry on lines somewhat similar to those followed by the Commission on Physical Training, and obtained their hearty approval.

In carying out the inquiry, I was fortunate in obtaining the cooperation of Drs. Kay, Wright Thomson, and Edwards, on whom, incleed, fell the whole work of the inquiry, ny own part being limited simply to arranging the details of the examination and making some suggestions as to the tabulation of results. For convenience of comparison, also, I had agreed with $\mathrm{Dr}$. Leslie MacKenzie to adopt the Schedule A which is now incorporated in his rolume on the subject, and through his courtesy I was able to obtain advance copies of the schedule before that work was issued.

The first object of the inquiry was to obtain comparative results, and for this purpose three schools were selected, in Cowcaddens District, in Calton, and again in Gorbals, in order that the observations taken there might be compared with corresponding observations taken in more healthy 


\section{Inquiry into the Physique of Glasgow Sshool Children.}

districts of the city. In order to cover these schools within the time at disposal, the number of children examined in each was limited to 150 (1save in the south-side school-where, an almost equal number of Jewish children being in attendance, 300 were taken, one-half being Christian and the other half Jews. In all the schools an equal number of eacth sex was taken, and the numbers were equally distributed over the individual years six to fourteen. The total number examined, thercfore, was 750 .

In carrying on the work the teachers of the various schools rendered us the most willing help, and filled in many of the cletails rewarding the general mental capacity of each child and its position in the class; the nationality of parents, size of house, \&c. Dr. Kay took charge of the measuring and weighing of the chillren, their condition as to complexion, cleanliness, state of nutrition, and the condition of their teeth, \&c. Dr. Edwards tested their hearing, and examined them with special refrence to affections of the throat, nose, skin, glands, heart, lungs, and abdomen, and for the detection of deformities; while Dr. Wright Thomson took sole charge of the examination of the eyes.

I began the inquiry in a district where the general cleath-rate was high, and then took two others in districts where the general death-rate was lower, but still above the mean rate for the city. After this a fourth school was taken in a district with a much lower general death-rate, and finally, through the courtesy of Dr. Spenser, Rector of the High Schuol, I obtained a record of measurements taken there with which to compare some of those taken by onrselves. There was a further advantage also, as well as a point of interest, in the presence of Jewish children in one of the schools drawn from the same district, and consequently housed under similar conditions with the Christian children attending the same school. It was found that by devoting about two hours in the forenoon of three days in the week, about fifty children could be examined per week.

At present I do not propose to clo more than indicate in a general way some of the results of this inquiry, and for this purpose I would refer to the Tables whicl have been prepared by Dr. Kay.

\section{Relation of Height to Weight.}

If reference be made to Table I. (Dr. Kay), it will be seen that for most ages the weight in pounds is slightly in excess of the height in inches. But there are exceptions. At age six, boys and girls have fractionally less than one pound in weight for each inch in lieight, and the same is true of girls at seven and eight. It will be observed also that the weight increased 
slightly more rapidly than the height. At age nine the ratio of height to weight is 1 to 1.05 for loys, and 1 to 1.07 for girls; while at fourteen it is 1 to 1.3 for both.

In Table III. it will be seen that the average weight of a male child at age six, measured during the present inquiry, was $39 \cdot 18 \mathrm{lbs}$, and the Edinburgh average wias $43.6 \mathrm{lbs}$; while the standard weight of the Anthropometric Committee of the British Association (1843 Report) is $44.4 \mathrm{lbs}$, and in our especially selected schools $44.7 \mathrm{lbs}$. At the age of seven the figures were, Glasgow 46.6, Edinburgh $46 \cdot 8$, and the Anthropometric Committce $49 \cdot 7$. Generally, it may be said that the Edinburgh children measured weiglı more at school ages than those of the present incuiry, but between seven and eleren are somewhat less in height, and that the High School boys at most ages are heavier and taller than the chillien (on whom the Anthropometric Committce based thcir averages. It must be kept in view, however, that you are dealing in the High School with selected boys, who might be called the "better fed." In heiglit and weirght the Anthropometric Committee's average is in excess of both towns, confirming in some degree the opinion of that Committee, that the children of towns, at corresponding ages, are smaller and lighter thin those bronght up in the country. On the other hand, the High School boys, at some ages, are taller and heavier than the Anthropometric figures, and would seem to indicate that town children under lealthy conditions of housing and suitable food are not necessarily decarfed either in height or weight. (Tables $7 \AA$ and $7 \mathrm{~B}$, Dr. Kay.)

I should like, further, to ask your attention to the results of the analysis when we attempted to grade the children according to the size of the louse in which they lived. This forms a most suggestive part of the inquiry. Grading them as belonging to one room, two rooms, and three rooms or more, the average height of girls from one-apartment houses is 43.4 inches, from the two-apartment houses $49 \cdot 2$, and from threeapartments and upwards 50 . The average weight of girls from oneapartment houses is $48 \cdot 8 \mathrm{lbs}$., from two-apartment houses $56 \mathrm{lbs}$, and from three and upwards $58 \mathrm{lbs}$. In boys corresponding differences are shown. In those from one-apartment houses the average height is $47 \cdot 7$ inches, from two-apartment houses 49, and from three apartments and upwards 50 . The average weight of boys from one-apartment houses is $52 \cdot 9 \mathrm{lbs}$, from two-apartment houses 56.6 , and from three-apartment houses and upwards $59 \cdot 6$ lbs. All this suggests that when we talk of one, two, and threeroomed conditions of living we are dealing largely with the conditions of an economic standard: that just as people live in a one-roomed house, so it 


\section{Inquiry into the Physique of Glasgow School Children.}

might be said that they are clotherl and fed in a one-roomed manner. That is, they are deficient in house-room and in food; but as affecting the children, at least, this latter is of most importance, although the evidence would seem to point to unsuitableness rather than lack of quantity in the food stuffs as most requiring attention.

In any further inquiry, we want precise information as to the nature of the dicts uned. I have been impressed by what I have already been able to ascertain in this respect, of the conditions of food supplies among the poor, but these are so different from our accustomed st:mindards as to lead to the introduction of a new set of factors. We ordinarily think of food purchised in pounds or ounces, but among the poor it is bought in pennyworths, and has little or no definite relation to weight. It is broken bread or meat parings. With regard to the broken bread, it must be clearly understood that it is not bat bread; on the contrary, it is quite good. Broken bread, such as is bought by the poor, is bread which has been broken in the oren in the process of firing, and is unfit for sale to the ordinary customers. In the same manner, fish which has not found a market during the day is sold at a reduced price; and there are many hundreds of families who are daily living in this way, and consequently in a manner far removed from the ordinary standard of food quantities.

Another suggestion which is the outcome of the inguiry is that if you are to have physical training in schools it is quite obvious that you must either select your children or adapt the exercises to the children. This seems to me essential. You cannot take a child whose weight and other measurements indicate physical unfitness, and put it under a definite routine system of drill without first inquiring if, say, the heart and lungs are in a perfectly healthy state.

With these few remarks, I shall conclude; but I would warn you that the analysis here given is not to be taken as applicable to the children of Glasgow generally, unless supported by an extension of the observations over a larger number of children. Further, that the results arrived at in the course of this investigation indicate to my mind that we have established a clear case for further inquiry, both with regard to the physique of our school children and also with reference to the dietary of the poor.

[For Discussion on this Paper, see page 938.] 